Isnawati, Zuhrotul Isnaini, E Indria Puspitasari L.; Analisis Variasi dan Tingkat.....

\title{
ANALISIS VARIASI DAN TINGKAT AKURASI PERHITUNGAN PAJAK PENGHASILAN (PPH) PASAL 23 DI KOTA MATARAM"
}

\author{
Isnawati \\ Zuhrotul Isnaini \\ Indria Puspitasari Lenap
}

\begin{abstract}
Abstrak
Pajak penghasilan (PPh) pasal 23 adalah pajak yang dipotong atas penghasilan yang berasal dari modal, penyerahan jasa, atau hadiah dan penghargaan, selain yang telah dipotong PPh Pasal 21. Aturan mengenai PPh Pasal 23 ini seringkali mengalami perubahan. Dharma (2007:1) menyatakan bahwa seiiring dengan perkembangan usaha, Direktur Jenderal Pajak melakukan perubahan terhadap Keputusan Direktur Jenderal Pajak Nomor KEP-170/PJ/2002 tentang Jenis Jasa lain dan Perkiraan Penghasilan Neto sebagaimana dimaksud dalam Pasal 23 ayat (1) huruf c Undang-Undang Nomor 7 Tahun 1983 tentang Pajak Penghasilan sebagaimana telah diubah terkahir dengan Undang-Undang Nomor 17 Tahun 2000. Dengan telah dikeluarkannya 1 (satu) Keputusan Direktur Jenderal Pajak dan 2 (dua) Peraturan Direktur Jenderal Pajak tentang Jenis Jasa Lain dan Perkiraan Penghasilan Netto PPh.Pasal 23 yang mempunyai masa berlaku yang berbeda, disamping itu perbedaan paling menonjol dari ketiga peraturan tersebut adalah masalah perkiraan penghasilan netto dan pengaturan mengenai obyek penyerahan yang harus dipotong PPh. Pasal 23. Apabila fiskus maupun wajib pajak kurang cermat, maka dampaknya akan mempengaruhi hak dan kewajibannya dibindang perpajakan. Kekhawatiran yang dinyatakan oleh Dharma tersebut tentunya berlaku juga untuk wilayah Kota Mataram, mengingat Kota Mataram berada di wilayah propinsi Nusa Tenggara Barat (NTB) yang merupakan propinsi dengan peringkat ke 27 dari 34 propinsi di Indonesia. Berdasarkan latar belakang tersebut, maka perlu dilakukan penelitian untuk mengetahui bagaimana cara fiskus maupun wajib pajak menghitung PPh.Pasal 23 tersebut. Selain itu penelitian ini perlu dilakukan untuk mengetahui seberapa akurat perhitungan yang dilakukan untuk PPh Pasal 23 tersebut. Penelitian ini merupakan Penelitian Deskriptif dengan menggunakan studi pustaka, yaitu menganalisa data yang sudah tertuang pada Laporan PKL Mahasiswa Prodi DIII Perpajakan FEB Unram. Dan hasil penelitian ini menggambarkan bahwa variasi perhitungan PPh Pasal 23 yang terdappat di Kota Mataram menggunakan tarif terbaru yaitu $2 \%$ dan $15 \%$ dikalikan dengan penghasilan Bruto. Tidak ditemukan pada sampel bahwa masih ada perusahaan maupun instansi yang masih menggunakan
\end{abstract}


tarif yang lama seperti yang dilaporkan pada salah satu Laporan PKL mahasiswa Prodi D-III Perpajakan FEB Unram. Adapun kesalahan tersebut murni bersumber dari mahasiswa yang masih kurang memahami mengenai perhitungan PPh Pasal 23 tersebut

Kata Kunci: Variasi Perhitungan; Tingkat Akurasi; PPh Pasal 23.

\section{Latar Belakang}

\section{PENDAHULUAN}

Pajak dipungut berdasarkan atau dengan kekuatan undang-undang serta aturan pelaksanaannya. System pemungutan pajak di Indonesia dibedakan menjadi tiga (3) yaitu system official assessment, system self assessment dan system withholding. Dalam system official assessment, fiskus aktif menghitung dan menetapkan besarnya pajak terutang dan wajib pajak akan membayar jumlah tersebut sesuai dengan batas waktu yang ditetapkan. System self assessment, wajib pajak sendiri yang akan menghitung, menyetorkan dan melaporkan pajak yang terutang. Fiskus berperan dalam melakukan penelitan atas kelengkapan dan kebenaran pelaporan serta melakukan pemerikasaan untuk mengetahui kebenaran materi dalam laporan wajib pajak, atau dalam hal ini Surat Pemberitahuan (SPT). Sedangkan system withholding, pihak ketiga yang berhubungan dengan wajib pajak (withholding agents) yang wajib menghitung, menetapkan, menyetorkan dan melaporkan pajak yang dipotongnya Rosdiana (2005; 108-109).

Tabel 1. Prosentase Rincian PPh Nonmigas terhadap Total PPh Nomigas 2001-2008

\begin{tabular}{lllllllll}
\hline Jenis & & & & & & & \\
Pajak/Rasio & 2001 & 2002 & 2003 & 2004 & 2005 & 2006 & 2007 & 2008 \\
\hline PPh 21/26 & $27 \%$ & $24 \%$ & $28 \%$ & $28 \%$ & $28 \%$ & $22 \%$ & $22 \%$ & $22 \%$ \\
PPh 22 & $10 \%$ & $9 \%$ & $8 \%$ & $9 \%$ & $9 \%$ & $11 \%$ & $12 \%$ & $11 \%$ \\
PPh 23 & $22 \%$ & $17 \%$ & $15 \%$ & $10 \%$ & $10 \%$ & $11 \%$ & $11 \%$ & $10 \%$ \\
PPh Final\&Fiskal & $2 \%$ & $15 \%$ & $12 \%$ & $13 \%$ & $13 \%$ & $15 \%$ & $15 \%$ & $15 \%$ \\
PPh 25/29 OP & $4 \%$ & $2 \%$ & $1 \%$ & $2 \%$ & $2 \%$ & $1 \%$ & $1 \%$ & $1 \%$ \\
PPh 25/29 badan & $35 \%$ & $33 \%$ & $36 \%$ & $38 \%$ & $38 \%$ & $40 \%$ & $39 \%$ & $41 \%$ \\
Total & $100 \%$ & $100 \%$ & $100 \%$ & $100 \%$ & $100 \%$ & $100 \%$ & $100 \%$ & $100 \%$ \\
\hline
\end{tabular}

Sumber: Undang-undang APBBN 2001-2008

Di Indonesia, pajak yang dipungut secara withholding salah satunya adalah Pajak Penghasilan (PPh), yaitu PPh pasal 21; PPh Pasal 22; PPh Pasal 23; PPh Pasal 26 dan PPh Final. Tabel 1 di bawah ini menunjukkan gambaran 
prosentase rincian PPh Nonmigas terhadap Total PPh Nonmigas dari tahun 2001 hingga tahun 2008 berdasarkan data APBN Republik Indonesia.

Pada tabel 1 di atas, tampak bahwa dari sisi prosentase terhadap Total anggaran PPh nonmigas. Peranan PPh pasal 23 cukup signifikan, akan tetapi dari tahun ke tahun mengalami penurunan.

Pajak penghasilan (PPh) pasal 23 adalah pajak yang dipotong atas penghasilan yang berasal dari modal, penyerahan jasa, atau hadiah dan penghargaan, selain yang telah dipotong PPh Pasal 21. Aturan mengenai PPh Pasal 23 ini seringkali mengalami perubahan.

Dharma (2007:1) menyatakan bahwa seiiring dengan perkembangan usaha, Direktur Jenderal Pajak melakukan perubahan terhadap Keputusan Direktur Jenderal Pajak Nomor KEP-170/PJ/2002 tentang Jenis Jasa lain dan Perkiraan Penghasilan Neto sebagaimana dimaksud dalam Pasal 23 ayat (1) huruf c Undang-Undang Nomor 7 Tahun 1983 tentang Pajak Penghasilan sebagaimana telah diubah terkahir dengan Undang-Undang Nomor 17 Tahun 2000. Pada tanggal 26 Desember 2006 Direktur Jenderal Pajak telah mengeluarkan Peraturan Direktur Jenderal Pajak Nomor: Per-178/PJ/2006 tentang Jenis jasa lain dan Perkiraan Penghasilan Netto sebagaimana dimaksud dalam pasal 23 ayat (1) huruf c Undang-Undang Nomor 7 tahun 1983 tentang pajak Penghasilan sebagaimana telah diubah terakhir dengan Undang-Undang Nomor 17 Tahun 2000. Peraturan ini berlaku terhitung mulai tanggal 1 Januari tahun 2007 sampai dengan tanggal 8 April 2007. Namun Per-178/PJ/2006 baru berlaku 3 (tiga) bulan, Direktur Jenderal Pajak pada Tanggal 9 April 2007 mengeluarkan Peraturan Direktur Jenderal Pajak Nomor: Per-70 PJ/2007 tentang Jenis Jasa Lain dan Perkiraan Penghasilan Netto sebagaimana dimaksud dalam Pasal 23 ayat (1) huruf c UndangUndang Nomor \& tahun 1983 Tentang Pajak Penghasilan sebagaimana telah beberapa kali diubah terakhir dengan Undang-Undang Nomor 17 tahun 2000. Per-70/PJ/2007 ini berlaku terhitung mulai 9 April 2007.

Lebih lanjut Dharma (2007:2) menyatakan bahwa dengan telah dikeluarkannya 1 (satu) Keputusan Direktur Jenderal Pajak dan 2 (dua) Peraturan Direktur Jenderal Pajak tentang Jenis Jasa Lain dan Perkiraan Penghasilan Netto PPh.Pasal 23 yang mempunyai masa berlaku yang berbeda, disamping itu perbedaan paling menonjol dari ketiga peraturan tersebut adalah masalah perkiraan penghasilan netto dan pengaturan mengenai obyek penyerahan yang harus dipotong PPh. Pasal 23. Apabila fiskus maupun wajib pajak kurang cermat, maka dampaknya akan mempengaruhi hak dan kewajibannya dibindang perpajakan.

Kekhawatiran yang dinyatakan oleh Dharma tersebut tentunya berlaku juga untuk wilayak Kota Mataram, mengingat Kota Mataram berada di 
wilayah propinsi Nusa Tenggara Barat (NTB) yang merupakan propinsi dengan peringkat ke 27 dari 34 propinsi di Indonesia. Peringkat tersebut menunjukkan bagaimana propinsi NTB masih memiliki banyak keterbatasan jika dibandingkan dengan propinsi yang memiliki peringkat lebih atas dibandingkan dengan NTB. Salah satunya adalah keterbatasan sumber daya manusia yang dimiliki, terutama dalam hal kualitas pendidikan yang dimiliki oleh propinsi NTB (http://infopublik.id).

Berdasarkan latar belakang tersebut, maka perlu dilakukan penelitian untuk mengetahui bagaimana cara fiskus maupun wajib pajak menghitung PPh.Pasal 23 tersebut. Selain itu penelitian ini perlu dilakukan untuk mengetahui seberapa akurat perhitungan yang dilakukan untuk PPh Pasal 23 tersebut. Dengan demikian diusulkan penelitian yang berjudul " Analisis Variasi dan Tingkat Akurasi Perhitungan PPh.Pasal 23 di Kota Mataram".

\section{Perumusan Masalah}

Berdasarkan latar belakang di atas, maka dapat dirumuskan permasalahan penelitian sebagai berikut:

1. Bagaimanakah variasi cara Wajib Pajak di Kota Mataram menghitung Pajak Penghasilan (PPh) Pasal 23.

2. Bagaimanakah tingkat akurasi perhitungan Pajak Penghasilan (PPh) Pasal 23 yang dilakukan oleh Wajib Pajak di Kota Mataram.

\section{TINJAUAN PUSTAKA}

\section{Tinjauan Penelitian Terdahulu} adalah:

Beberapa penelitian terdahulu yang dijadikan acuan dalam penelitian ini

1. Penelitian yang dilakukan oleh Sadjiarto (2010) meneliti mengenai Variasi Perhitungan dan Penyetoran Pajak Penghasilan (PPh) Pasal 21. Hasil penelitian ini menunjukkan bahwa di tahun 2006 ada perbedaan perhitungan dan penyetoran PPh Pasal 23 antara yang dilakukan PT X dengan yang diatur oleh peraturan perpajakan, khususnya untuk pegawai tetap dan tidak tetap (harian). Variasi cara perhitungan dilakukan pada pegawai tetap karena adanya perhitungan ulang saat penyusunan SPT PPh Pasal 21 Tahunan dan pada pegawai harian karena penyederhanaan cara perhitungan PPh 21/26 yang dianggap relative rumit.

2. Penelitian yang dilakukan oleh Widiyatmini (2009) melakukan analisis perhitungan Pajak Penghasilan Badan pada Dua Perusahaan Industri Jasa Telekomunikasi (PT.Excelcomindo Pratama Tbk. Dan PT.Indosat Tbk). Hasil analisis menunjukkan bahwa setiap perusahaan telah melaksanakan 
Isnawati, Zuhrotul Isnaini, E Indria Puspitasari L.; Analisis Variasi dan Tingkat.....

kewajiban formal yaitu melaksanakan pembukuan, pelaporan dan pembayaran pajak secara teratur, serta telah melaksanakan pelaporan Pajak Penghasilan pada SPT Tahunan, sesuai dengan ketentuan. Hal ini dibuktikan dengan dilakukannya koreksi positif atas biaya yang non taxable.

3. Penelitian yang dilakukan oleh Febriyanti (2013). Penelitian ini bertujuan untuk menganalisis penerapan pemotongan pajak penghasilan pasal 23 atas jasa perawatan, pemeliharaan dan perbaikan kendaraan pada CV.Anugrah Multi Sarana. Metode penelitian ini menggunakan pendekatan penelitian kualitatif yaitu mengumpulkan data, mengolah data, menganalisis data, kemudian mengambil kesimpulan. Hasil dari penelitian ini bahwa CV.Anugrah Multi Sarana pada tahun 2011 - 2012, terdapat perbedaan tariff pemotongan pajak penghasilan pasal 23 peraturan perundang-undangan perpajakan No.36 Tahun 2008 sehingga terdapat selisih atas perbedaan perhitungan tersebut.

4. Penelitian yang dilakukan oleh Manengkey dkk. (201 5) bertujuan untuk mengetahui dampak pemahaman wajib pajak atas PP No 46 tahun 2013 terhadap penerimaan pajak penghasilan pasal 21 pada KPP Prataman Kotamobagu. Jenis penelitian yang digunakan dalam penelitian ini adalah penelitian Asosiatif. Hasil yang disimpulkan bahwa penelitian ini menerima hipotesis yaitu pemahaman wajib pajak atas PP No.4 6 tahun 2013 berpengaruh terhadap penerimaan pajak penghasilan pasal 21 (PPh Pasal 21).

\section{Tinjauan Teoritis}

\section{Pengertian Penghasilan}

Penghasilan berdasarkan pasal 4 (1) UU No. 17/2000 atau diringkas UU PPh adalah setiap tambahan kemampuan ekonomi yang diterima atau diperoleh Wajib Pajak, baik berasal dari Indonesia maupun dari luar Indonesia, yang dapat dipakai untuk konsumsi atau untuk menambah kekayaan Wajib Pajak yang bersangkutan, dnegan nama dalam bentuk apapun (Muljono:2007:27).

\section{Pengertian Pajak Penghasilan (PPh) Pasal 23}

PPh Pasal 23 adalah penyetoran pajak penghasilan dalam tahun berjalan yang dipotong atas penghasilan yang diterima oleh Wajib Pajak dalam negeri dan BUT yang berasal dari modal. Penyerahan jasa, atau penyelenggaraan kegiatan selain yang telah dipotong PPh.Pasal 21 (Dharma: 2007:3). 


\section{Subyek Pemotong dan Subyek Penerima Penghasilan Yang dipotong Pajak Penghasilan (PPh) Pasal 23}

Subyek yang dimaksud menjadi pemotong PPh. Pasal 23 sebagaimana dimaksud dalam pasal 23 ayat (1) UU PPh adalah:

- Badan Pemerintah

- Subyek Pajak Badan Dalam Negeri

- Penyelenggaraan Kegiatan

- Bentuk Usaha Tetap (BUT)

- Perwakilan Perusahaan Luar Negeri Lainnya

- Wajib Pajak Orang Pribadi yang ditunjuk sebagai Pemotong Pajak Penghasilan Pasal 23 (Per-70/PJ./2007 Lampiran III angka 1 huruf a)

- Akuntan, arsitk, Dokter, Notaris, Pejabat Pembuat Akta Tanah (PPAT) Kecuali Camat, Pengacara, dan Konsultan, yang melakukan pekerjaan bebas.

- Orang pribadi yang menjalankan usaha yang menyelenggarakan pembukuan, atas pembayaran berupa sewa.

Subyek penerima penghasilan yang dipotong PPh Pasal 23 sebagaimana dimaksud dalam Pasal 23 ayat (1) UU.PPh. adalah:

a. Wajib Pajak Dalam Negeri

b. Badan Usaha Tetap (BUT)

\section{Obyek PPh Pasal 23}

Yang menjadi obyek Pajak Penghasilan (PPh) Pasal 23 adalah sebagai berikut:

a. Deviden, dengan nama dan dalam bentuk apapun, termasuk deviden dari perusahaan asuransi kepada pemegang polis, dan pembagian sisa hasil usaha koperasi sebagaimana dimaksud dalam pasal 4 ayat (1) huruf $g$ UU.PPh;

b. Bunga, termasuk premium, diskonto dan imbalan sehubungan dengan jaminan pengembalian hutang sebagaimana dimaksud dalam pasal 4 ayat (1) huruf f UU.PPh.;

c. Royalti;

d. Hadiah dan penghargaan selain yang dikenakan PPh. Pasal 21 ayat (1) huruf e UU.PPh.;

e. Bunga simpanan yang dibayarkan oleh koperasi (bersifat final);

f. Sewa dan penghasilan lain sehubungan dengan penggunaan harta kecuali sewa tanah dan/atau bangunan (sewa atas tanah dan/atau bangunan diatur tersendiri dengan PPh.Pasal 4 ayat (2) UU.PPh.); 
Isnawati, Zuhrotul Isnaini, E Indria Puspitasari L.; Analisis Variasi dan Tingkat.....

g. Imbalan sehubungan dengan jasa teknik, jasa manajemen, jasa konsultan, jasa konstruksi dan jasa lain selain jasa yang telah dipotong PPh.Pasal 21;

Jadi setiap penghasilan (huruf a sampai dengan huruf e) yang diterima Wajib Pajak Dalam Negeri dan BUT merupakan Obyek Pajak Penghasilan Pasal 23.

\section{Saat Terutang PPh.Pasal 23}

Batas waktu pelaksanaan kewajiban Pemotongan Pajak Penghasilan Pasal 23 dikaitkan dengan saat penyetoran atau saat terhutangnya penghasilan. Saat terhutangnya penghasilan tersebut lazimnya adalah pada saat jatuh tempo (seperti Bunga dan sewa), saat tersedia untuk dibayarkan (seperti: Deviden), saat yang ditentukan dalam kontrak /Perjanjian atau faktur (seperti: Royalti, imbalan jasa teknik/ jasa manajemen/jasa lainnya), atau saat tertentu lainnya. Saat terhutangnya penghasilan tersebut juga ditentukan berdasarkan saat pengakuan biaya sesuai dengan metode pembukuan yang dianut oleh Pihak yang berkewajiban memotong atau memungut Pajak Penghasilan.

\section{Dasar Pengenaan PPh.Pasal 23} adalah:

Yang menjadi Dasar Pengenaan Pajak Penghasilan (PPh) Pasal 23

1. Penghasilan Bruto

Penghasilan Bruto adalah penghasilan yang diterima oleh Wajib Pajak dalam menjalankan kegiatan usahanya tanpa adanya pengurangan.

2. Perkiraan Penghasilan Netto

Perkiraan Penghasilan Netto adalah persentase tertentu yang besarnya telah tercantum dalam Peraturan Perpajakan yang berlaku yaitu:

- Peraturan Direktur jenderal Pajak Nomor: Per-70/PJ/2007 Tanggal 9 April 2007, menggantikan:

- Peraturan Direktur Jenderal Pajak Nomor: Per-178/PJ/2006 Tanggal 26 Desember 2006, menggantikan:

- Keputusan Direktur Jenderal Pajak Nomor: KEP-170/PJ/2002 tanggal 28 Maret 2002.

Terhitung mulai tanggal 9 April 2007 yang menjadi Pedoman Pelaksanaan Perkiraan Penghasilan Netto adalah berdasarkan Per70/PJ/2007. Dan terhitung mulai 23 Agustus 2015, daftar perusahaan yang wajib memotong PPh Pasal 23 semakin banyak karena Objek PPh Pasal 23 dari jenis penghasilan lainnya diperluas dengan Peraturan Menteri Keuangan Nomor 141/PMK.03/2015. 


\section{RERANGKA PEMIKIRAN PENELITIAN}

Penelitian ini merupakan penelitian deskriptif yaitu penelitian yang bertujuan untuk memberikan atau menjabarkan suatu keadaan atau fenomena yang terjadi saat ini dengan menggunakan prosedur ilmiah untuk menjawab masalah actual. Keadaan yang ingin dijabarkan dalam penelitian ini adalah kualitas atau tingkat keakuratan perhitungan PPh Pasal 23 yang dilakukan oleh fiskus/Wajib Pajak. Penelitian ini didasari oleh seringnya dilakukan perubahan atas aturan PPh khususnya PPh Pasal 23 oleh Dirjen Pajak. Lebih jelasnya, gambaran penelitian dapat dilihat pada gambar 1 di bawah ini:

Gambar 1. Rerangka Pemikiran Penelitian

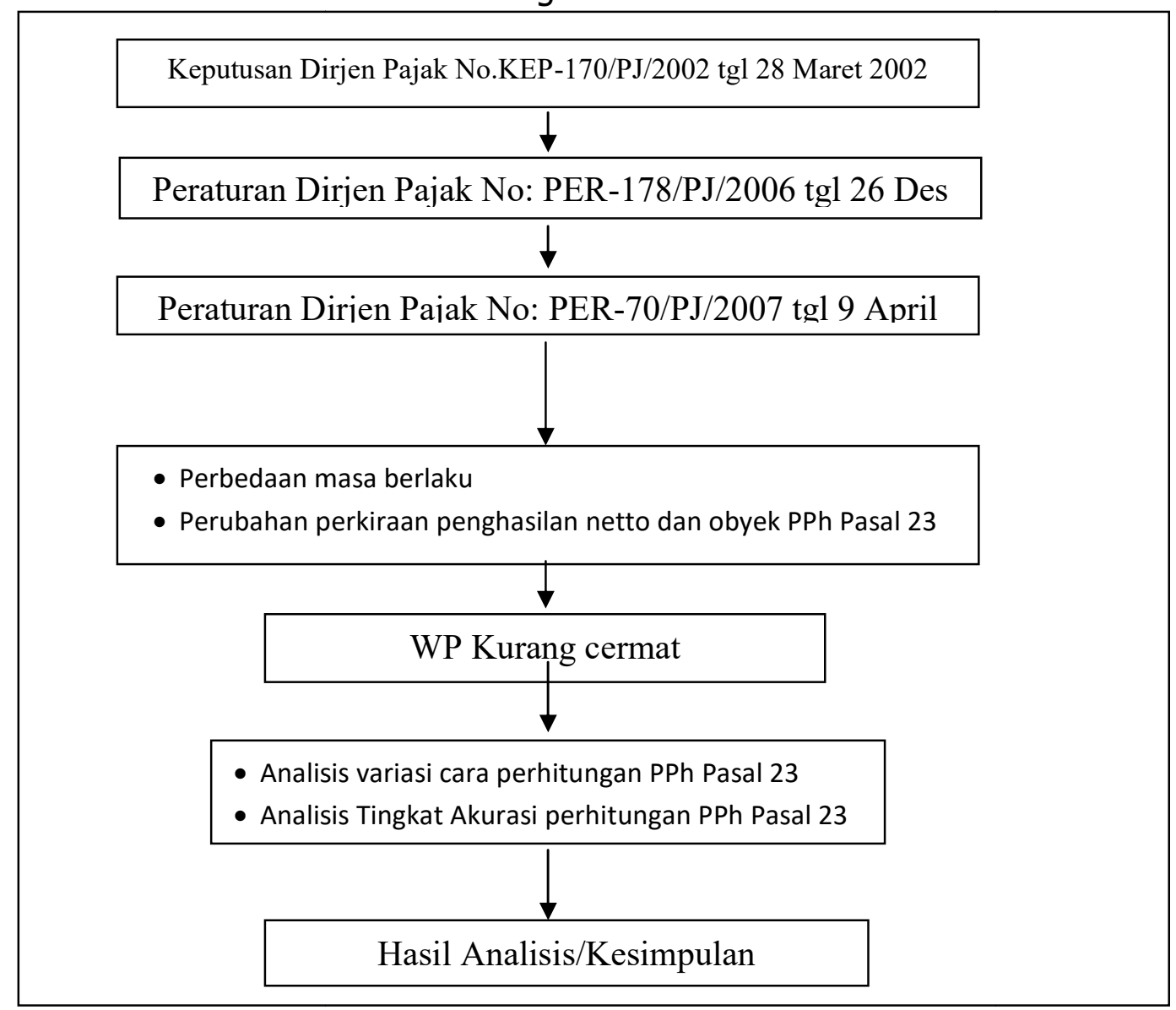


Isnawati, Zuhrotul Isnaini, E Indria Puspitasari L.; Analisis Variasi dan Tingkat.....

\section{Jenis Penelitian}

Jenis penelitian ini adalah penelitian deskriptif. Menurut Sugiyono (2011), penelitian deskriptif adalah sebuah penelitian yang bertujuan untuk memberikan atau menjabarkan suatu keadaan atau fenomena yang terjadi saat ini dengan menggunakan prosedur ilmiah untuk menjawab masalah actual. Sedangkan menurut Sukmadinata (2006) menyatakan bahwa metode penelitian deksriptif adalah sebuah metode yang berusaha mendeskripsikan, menginterpretasikan sesuatu, misalnya kondisi atau hubungan yang ada, pendapat yang berkembang, proses yang sedang berlangsung akibat atau efek yang terjadi atau tentang kecendrungan yang sedang berlangsung.

\section{Prosedur Pengumpulan Data dan Sumber Data}

Pengumpulan data dilakukan dengan teknik studi kepustakaan atau biasa dikenal dengan istilah library research. Data penelitian ini adalah data sekunder. Data sekunder berupa hasil Laporan PKL Mahasiswa Prodi D3 Perpajakan yang khusus mengangkat tema Perhitungan Pajak Penghasilan (PPh) Pasal 23. Sumber data lainnya berupa studi kepustakaan, untuk mencari teori-teori yang berhubungan dengan topik penelitian.

\section{Sampel Penelitian}

Sampel menurut Sugiyono (2007:56) adalah sebagian dari jumlah dan karakteristik yang dimiliki oleh populasi tersebut. penelitian ini menggunakan teknik sampling Aksidental yaitu teknik penentuan sampel berdasarkan kebetulan. Karena teknik pengumpulan datanya menggunakan studi pustaka, yaitu menggunakan hasil Laporan PKL Mahasiswa Prodi D3 Perpajakan yang mengangkat tema Perhitungan PPh Pasal 23 di Kota Mataram.

\section{Definisi Operasional Variabel}

Variabel dalam penelitian ini adalah PPh Pasal 23. PPh Pasal 23 itu sendiri merupakan penyetoran Pajak Penghasilan dalam tahun berjalan yang dipotong atas penghasilan yang diterima oleh Wajib Pajak dalam negeri dan BUT yang berasal dari modal, penyerahan jasa, atau penyelenggaraan kegiatan selain yang telah dipotong PPh.Pasal 21.

\section{Teknik Analisis Data}

Data data yang telah diperoleh pada saat pengumpulan data akan diolah dengan menggunakan metode analisis deskriptif. Dalam mengolah data data penelitian, maka penulis melakukan langkah langkah sebagai berikut: 
a. Tahap Pertama

Langkah pertama yang dilakukan dalam mengolah data yaitu dengan cara menentukan buku buku dan teori yang akan digunakan, khususnya peraturan perpajakan yang masih berlaku mengenai PPh Pasal 23 yaitu:

1. Peraturan Direktur Jenderal Pajak Nomor: PER 70/PJ/2007 tentang jenis jasa lain dan perkiraan penghasilan Netto.

2. Peraturan Menteri Keuangan Nomor 141/PMK.03/2015 tentang tambahan jenis jasa lain yang dikenakan PPh Pasal 23.

b. Tahap Kedua

Langkah selanjutnya yaitu mengumpulkan data data perhitungan PPh Pasal 23 yang dilakukan oleh Wajib Pajak di Kota Mataram sejak tahun 2006 sampai dengan tahun 2015. Data ini didapatkan secara aksidental dari hasil laporan PKL Mahasiswa Prodi D3 Perpajakan yang diarsipkan di perpustakaan FEB Unram maupun Ruang baca Prodi D3 Perpajakan.

c. Tahap Ketiga

Pada tahap ini dilakukan analisis terhadap data data yang sudah dikumpulkan. Analisis yang dilakukan adalah:

1. Menganalisis variasi cara perhitungan PPh Pasal 23 yang dilakukan oleh Wajib Pajak di Kota Mataram. Ada dua (2) cara perhitungan PPh Pasal 23 berdasarkan peraturan perpajakan yang berlaku yaitu:

Tarif PPh Pasal 23 x Jumlah Penghasilan

Tarif PPh Pasal 23 x Jumlah Perkiraan Penghasilan

2. Menganalisis tingkat akurasi perhitungan yang PPh Pasal 23 yang dilakukan oleh Wajib Pajak di Kota Mataram. Tingkat akurasi tersebut dapat ditentukan dengan menggunakan rumus sederhana berikut ini:

$$
\text { TAP PPhPasal } 23=\frac{\text { JumlahPerhitungan yang tepat }}{\text { Jumlahsampel Penelian }}
$$

Ket: TAP $=$ Tingkat Akurasi Perhitungan

d. Tahap Keempat

Setelah melakukan penguraian/analisis terhadap data data penelitian tersebut, langkah selanjutnya adalah membuat pembahasan sesuai dengan hasil penelitian tersebut. sebagai tahap akhir dilakukan generalisasi yang bertujuan untuk memperjelas hasil penelitian. 
Isnawati, Zuhrotul Isnaini, \& Indria Puspitasari L.; Analisis Variasi dan Tingkat.....

\section{HASIL DAN PEMBAHASAN}

\section{Gambaran Umum Objek Penelitian}

Mataram sebagai salah satu Kota di Propinsi Nusa Tenggara Barat, letaknya diapit antara kabupaten Lombok Barat dan Selat Lombok. Wilayah kota Mataram adalah $61,30 \mathrm{Km} 2$, yang terbagi dalam 6 kecamatan. Kecamatan terluas adalah Selaparang yaitu sebesar 10,7653 Km2, disusul Kecamatan Mataram dengan luas wilayah 10,7647 Km2. Sedangkan wilayah terkecil adalah Kecamatan Ampenan dengan luas 9,4600 Km2. Berdasar Peraturan Daerah Kota Mataram; Nomor : 3 Tahun 2007, Tentang Pemekaran Kecamatan dan Kelurahan di Kota Mataram maka kecamatan yang belumnya berjumlah 3 (tiga) kecamatan dimekarkan menjadi 6 (enam) dengan 50 ( limapuluh) kelurahan dan 298 lingkungan.

Kota Mataram merupakan Ibu Kota Provinsi Nusa Tenggara Barat, tentunya semua kegiatan terpusat di Kota Mataram tersebut. Mulai dari kegiatan pemerintahan, kegiatan perekonomian maupun kegiatan yang lainnya. Khusus untuk menggambarkan mengenai variasi dan tingkat akurasi perhitungan PPh Pasal 23 yang terdapat di Kota Mataram, maka data penelitian di peroleh dengan cara studi pustaka melalui Laporan PKL mahasiswa Prodi D-III Perpajakan FEB Universitas Mataram yang khusus mengangkat tema PPh Pasal 23. Alasan penggunaan data ini mengingat mahasiswa Prodi D-III Perpajakan sebagian besar melakukan kegiatan PKL di Kota Mataram.

\section{Deskripsi Data Penelitian}

Data penelitian ini diambil dengan menggunakan studi pustaka melalui Laporan PKL mahasiswa Prodi D-III Perpajakan FEB Unram. Berikut adalah gambaran jumlah pengajuan judul laporan PKL sejak semester Gasal 2012/2013 sampai dengan semester Genap 2015/2016. 
Tabel 2. Jumlah Pengajuan Judul Laporan Praktik Kerja Lapangan (PKL) Prodi D-III Perpajakan FEB Unram

\begin{tabular}{|r|l|l|l|}
\hline No & Tahun/Semester & $\begin{array}{l}\text { Jumlah Pudul } \\
\text { Jud }\end{array}$ & Pertahun \\
\hline 1 & Gasal 2012/2013 & 6 Judul & \\
2 & Genap 2012/2013 & 171 Judul & 177 Judul \\
3 & Gasal 2013/2014 & 4 Judul & \\
4 & Genap 2013/2014 & 162 Judul & 166 Judul \\
5 & Gasal 2014/2015 & 3 Judul & \\
6 & Genap 2014/2015 & 142 Judul & 145 Judul \\
7 & Gasal 2015/2016 & 0 Judul & \\
8 & Genap 2015/2016 & 142 Judul & 142 Judul \\
\hline \multicolumn{3}{|c|}{ Rata-Rata Pertahun } & 158 Judul \\
\hline
\end{tabular}

Sumber: Data Akademik Prodi D-III Perpajakan

Table 2 di atas memperlihatkan rata-rata pengajuan Judul Laporan PKL mahasiswa Prodi D-III Perpajakan sebanyak 158 Judul setiap tahunnya yang tersebar pada berbagai topic judul. Khusus yang mengangkat judul mengenai PPh Pasal 23 berkisar 6 sampai dengan 10 judul setiap tahunnya. Untuk penelitian ini menggunakan teknik aksidental sampling dalam pengambilan sampel penelitian. Berikut adalah sampel yang digunakan dalam penelitian ini:

Tabel 3. Jumlah Sampel Penelitian

\begin{tabular}{|c|c|c|}
\hline No & Tahun & Jumlah Sampel \\
\hline 1 & 2013 & 0 judul \\
\hline 2 & 2014 & 6 Judul \\
\hline 3 & 2015 & 13 Judul \\
\hline 4 & 2016 & 4 Judul \\
\hline & Jumlah & 23 Judul \\
\hline
\end{tabular}

Sumber: Data diolah

Table 3 di atas menunjukkan jumlah sampel yang digunakan dalam penelitian ini. 23 judul laporan PKL yang membahas tentang Perhitungan PPh Pasal 23 di berbagai instansi, Usaha baik di sekto Pemerintahan maupun sector swasta yang ada di Kota Mataram. 
Isnawati, Zuhrotul Isnaini, E Indria Puspitasari L.; Analisis Variasi dan Tingkat.....

\section{Hasil Penelitian}

Berdasarkan data tabulasi penelitian pada Lampiran 1, maka dapat dijelaskan bahwa pengenaan PPh Pasal 23 atas penggunaan jasa yang terjadi di Kota Mataram, sebagian besar dihitung dengan cara tarif dikalikan dengan Penghasilan Bruto. Tarif yang dikenakan sesuai aturan perpajakan yang berlaku di setiap tahunnya. Dan aturan yang terbaru saat ini adalah Peraturan Menteri Keuangan Republik Indonesia No: 141/PMK.03/2015. Dalam penelitian ini, menunjukkan angka $100 \%$ untuk sampel yang digunakan dalam penelitian ini. Artinya bahwa hampir seluruh instansi ataupun Badan Usaha baik sector Pemerintahan maupun Sektor swasta melakukan perhitungan PPh Pasal 23 menggunakan cara tarif dikalikan dengan Penghasilan Bruto. Hampir tidak ada yang menggunakan cara tarif dikalikan dengan perkiraan penghasilan Neto.

Sedangkan untuk tingkat akurasi perhitungan PPh Pasal 23 yang dilakukan di Kota Mataram bisa disimpulkan bahwa perhitungannya sudah dilakukan sesuai dengan aturan perpajakan yang berlaku di setiap tahunnya. Adapun pada saat dilakukan telaah pustaka terhadap Laporan PKL mahasiswa Prodi D-III Perpajakan FEB Unram, beberapa Laporan PKL keliru dalam mengungkapkan serta membandingkan antara teori dengan yang terjadi di praktiknya. Akan tetapi setelah dianalisa dengan seksama, kekeliruan dilakukan oleh pihak Mahasiswa. Dengan kata lain untuk praktik yang terjadi di Kota Mataram belum ditemukan kekeliruan di dalam perhitungan PPh Pasal 23 tersebut.

Berikut adalah beberapa kekeliruan mahasiswa yang berhasil ditemukan di dalam laporan PKLnya dalam mengungkapkan praktik perhitungan PPh Pasal 23 di Kota Mataram:

- Salah menggunakan tarif untuk menunjukkan yang terjadi di praktiknya. Pada salah satu Laporan PKL tersebut memberikan contoh perhitungan PPh Pasal 23 sebesar 6\% untuk Wajib Pajak yang tidak memiliki NPWP, padahal di SSP menunjukkan hasil perhitungan menggunakan 4\%. Aturan perpajakan yang berlaku menyatakan bahwa tarif PPh Pasal 23 sebesar $2 \%$ untuk WP yang memiliki NPWP, sedangkan bagi WP yang tidak memiliki NPWP dikenakan lebih besar $100 \%$.

- Salah satu Laporan PKL mahasiswa menunjukkan perhitungan PPh Pasal 23 dengan cara mengalikan tarif $\times$ (DPP $\times 10 \%$ ). Namun setelah dicocokkan dengan SSP yang dilampirkan, perhitungan yang dilakukan oleh praktiknya yaitu tarif $x$ DPP. 


\section{DAFTAR PUSTAKA}

Anonim, 2008. Tinjauan Atas Perhitungan, Pemotongan, dan Pelaporan PPh Pasal 23 Atas Jasa Pemasangan/Instalasi Listrik pada PT.PLN (Persero) Bandung.

Dharma, Mustika. 2007. Pelaksanaan Pemotongan, Penyetoran dan Pelaporan PPh Pasal 23 dari Masa Ke Masa. Graha Ilmu. Yogyakarta.

Direktorat Jenderal Pajak. 2013. Pajak Penghasilan. Jakarta.

Febrianti, Siska.; Kardinal. 2009. Evaluasi Penerapan Pemotongan Pajak Penghasilan Pasal 23 Atas Jasa Perawatan, Pemeliharaan dan Perbaikan Kendaraan pada CV.Anuggrah Multi Sarana. STIE MDP.

Harerisnowo. Perencanaan Pajak Penghasilan (PPh) Pasal 21 Karyawan tetap dalam upaya meminimalisasikan biaya pajak PT.Bank Internasional Indonesia (BII) Finance Center. Tesis. Universitas Indonesia. Jakarta.

http://infopublik.id/read/141/rendahnya-kualitas-pembangunan-manusia-dintb.html

http://pajaktaxes.blogspot.co.id/2015/08/mulai-agustus-2015-objekpemotongan-pph.html

Keputusan Direktur Jenderal Pajak Nomor KEP 06/PJ/2014 tentang Distribusi Rencana Penerimaan PPh, PPN dan PPn BM, Pajak Lainnya, serta PBB Perkantor wilayah DJP Tahun anggaran 2014.

Manengkey, Speny Ria; Sifrid Pangemanan; Winston Pontoh. 2015. Dampak Pemahaman Wajib Pajak atas PP Nomor 46 Tahun 2013 terhadap Penerimaan Pajak Penghasilan Pasal 21 pada KPP Pratama Kotamobagu. Jurnal Accountability Vol.4 No.1 Juni 2015, ISSN.2338 3917. Ratulangi.

Peraturan Direktur Jenderal Pajak Nomor 178/PJ/2006 tentang Jenis Jasa Lain dan Perkiraan Penghasilan Neto.

Rosdiana, haula dan Rasin Taringan. 2005. Perpajakan: teori dan Aplikasi. Raja Grafindo Persada. Jakarta.

Sadjiarto, Arja. 2008. Variasi Penghitungan dan Penyetoran Pajak Penghasilan Pasal 21. Jurnal Akuntansi dan keuangan, Vol.10 No.1 Mei 2008.Surabaya.

Sugiyono. 2011. Statistik untuk Penelitian. Alfabeta. Bandung.

Sukmadinata. 2006. Metode Penelitian Pendidikan. Remaja Rosdakarya. Bandung.

Tologana, Evalin Yuanita. 2015. Pengaruh Sanksi, Motivasi dan Tingkat Pendidikan terhadap Kepatuhan Wajib Pajak Orang Pribadi (Studi Kasus KPP Pratama Manado). Jurnal Accountability Vol.4 No.1 Juni 2015, ISSN.2338 3917. Ratulangi. 
Isnawati, Zuhrotul Isnaini, E Indria Puspitasari L.; Analisis Variasi dan Tingkat.....

Waluyo. 2010. Pengaruh Persepsi Wajib Pajak Orang Pribadi Atas Perubahan Undang Undang Terhadap Kewajiban Perpajakan. Jurnal AkuntansiTahun XIV/02/Mei/2010 ISSN : 1410 35.Jakarta.

Waluyo. 2013. Perpajakan Indonesia,Edisi 11 Buku 1. Salemba Empat. Jakarta.

Widyatmini, Gian Pratama Putra. 2010. Analisis Penghitungan Pajak Penghasilan Badan Pada Dua Perusahaan Industri Jasa Telekomunikasi (PT.Excelcomindo Pratama Tbk. Dan PT.Indosat Tbk.). Jurnal Jurusan Akuntansi Fakultas Ekonomi UNiversitas Gunadarma. 